\title{
Osteoporose por Desuso: Aplicação na Reabilitação do Lesado Medular
}

\author{
Disuse Ostoporosis: Its relationship to Spine Cord Injuried Patient Rehabilitation
}

\section{Daniela Cristina Leite de Carvalmo ${ }^{1}$, Mariângela Martins de Carvalho², Alberto Cliquet JR ${ }^{3}$}

\section{RESUMO}

A osteoporose é uma doença óssea metabólica muito freqüente em pacientes que sofreram lesão medular. Seu aparecimento pode prejudicar os tratamentos de reabilitação destes pacientes, devido à possibilidade de ocorrência de fraturas em seus ossos osteoporóticos. A osteoporose em lesados medulares está relacionada com o desuso causado pela paralisia, a qual provoca diminuição da tensão mecânica sobre os ossos, e consequentemente, diminuição do estímulo à formação de osso com aumento desproporcional da reabsorção óssea, tornando o osso mais frágil.

Assim, tratamentos alternativos não farmacológicos, baseados no princípio biomecânico do osso, estão sendo estudados, os quais incluem a análise da sustentação de peso causada pela estimulação elétrica neuro-muscular (EENM), e o ultra-som de baixa intensidade. Este artigo propõe explicar a importância do estímulo mecânico sobre os ossos e as conseqüências de sua ausência, com ênfase nos pacientes lesados medulares. Além de mostrar tratamentos alternativos que têm sido estudados.

Descritores: Osteoporose, Lesados Medulares, Biomecânica do Osso, EENM, Ultra-som.

\section{SUMMARY}

Osteoporosis is a very much frequent metabolic disease among spine cord injuried patients.

Their rehabilitation can be jeopardized by this disease, due to the possibility of fractures of the osteoporotic bones. Osteoporosis in spine injuried patients is related to the disuse caused by palsy, which leads to less mechanic stress over the bones, and as a consequence, less bone formation stimulation, with a not proportional bone absorption, which makes bone fragile.

Thus, alternative non pharmacological treatments based on bone biomechanics principles are under study, which include an analysis of weight bearing caused by neuromuscular electrical stimulation (NMES) and low intensity ultra sound. This article is proposed to explain the importance of mechanic stimulation over the bones and the consequences of its absence, with an emphasis on spine cord injuried patients, and to discuss alternative treatments already studied.

Key Words: Osteoporosis, Spine Cord Injuried Patients, Bone Biomechanics, NMES, Ultrasound.

\footnotetext{
* Trabalho realizado na Escola de Engenharia de São Carlos - Universidade de São Paulo (USP) no curso de Pós-Graduação Interunidades Bioengenharia e no Ambulatório do Departamento de Ortopedia e Traumatologia da Faculdade de Ciências Médicas- UNICAMP.

1. Fisioterapeuta - Aluna de Mestrado do Curso de Pós-Graduação Interunidades Bioengenharia (EESC/FMRP/IQSC-USP).

2. Fisioterapeuta do Serviço de Fisioterapia e Terapia Ocupacional do Hospital das Clínicas - UNICAMP.

Aluna de Mestrado do Departamento de Ortopedia e Traumatologia - FCM-UNICAMP.
} 3. Professor Titular EESC-USP/ FCM -UNICAMP

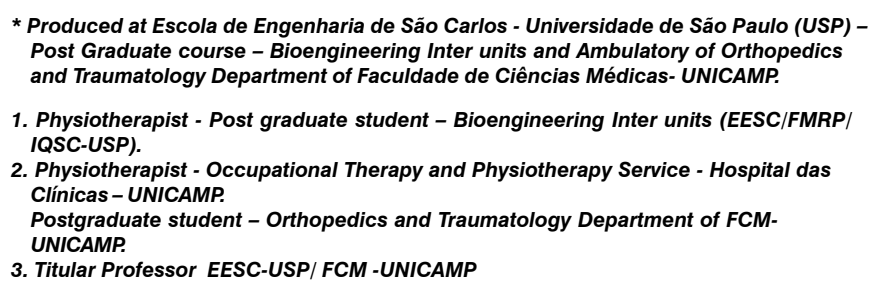

1. Physiotherapist - Post graduate student - Bioengineering Inter units (EESC/FMRP) IQSC-USP).

2. Physiotherapist - Occupational Therapy and Physiotherapy Service - Hospital das Clínicas - UNICAMP. Postgraduate student - Orthopedics and Traumatology Department of FCMUNICAMP.

3. Titular Professor EESC-USP/ FCM -UNICAMP 


\section{INTRODUÇÃO}

A osteoporose tem aparecido como grande problema de saúde pública, sendo principalmente atribuída ao aumento de expectativa de vida, aumentando assim, doenças relacionadas com a idade avançada. No entanto, a osteoporose tem etiologia multifatorial(1), podendo também estar presente em lesados medulares.

A lesão medular acarreta alterações em vários sistemas orgânicos, incluindo metabolismo de cálcio e o sistema ósseo ${ }^{(11)}$. A lesão medular inclui perda da função motora, geralmente irreversível, e diminuição da tensão mecânica sobre os ossos, devido à paralisia.

Embora parte da patofisiologia da osteoporose em lesados medulares seja atribuída ao desuso simples, esta se difere da osteoporose tradicional pelo fato do sistema neuromuscular, relacionado com outros sistemas do corpo estarem modificados para sempre. Acredita-se que as alterações provocadas pela falta de suporte de peso é muito mais prejudicial ao esqueleto que a falta de hormônio ovariano. Remoção aguda de carga mecânica causa uma diminuição mensal de 3\% a 6\% na massa dos ossos sob desuso, enquanto falta aguda de estrógeno causa diminuição anual de $4 \%$ a $5 \%$ de massa óssea ${ }^{(10)}$.

O quadro clínico de osteoporose ocorre pelo aumento desproporcional da reabsorção óssea, por suprimir o controle inibitório sobre osteoclastos, ocorrendo desequilíbrio no remodelamento ósseo(18), e talvez pelo aumento local de IL-6, abaixo do nível de lesão, em pacientes paraplégicos ${ }^{(10)}$.

Desta forma, o organismo não consegue fazer o remodelamento ósseo na mesma proporção que ocorre reabsorção, tornando o osso mais frágil e menos capaz de resistir a compressão e à torção, o que aumenta à incidência de fraturas. A redução na massa óssea é associada com uma obrigatória perda de estrutura óssea e, consequentemente, diminuição da força óssea. Portanto, a microarquitetura óssea tem importante função em determinar as propriedades mecânicas dos ossos.

Outros estudos têm demonstrado que em pessoas com lesão medular crônica o conteúdo mineral ósseo, comparado a indivíduos normais, diminui em 25\%, no fêmur proximal, e em 50\% na tíbia proximal(3).

Segundo JONES et al, 1998, pacientes paraplégicos só possuem $70 \%$ do conteúdo mineral ósseo (BMC) encontrado no grupo controle. Estas mudanças podem ser regionais.

Tanto em pacientes paraplégicos quanto tetraplégicos, a queda óssea é notada em todo esqueleto, exceto no crânio, principalmente nas extremidades inferiores, os quais encontram-se osteopênicos.

\section{INTRUDUCTION}

Osteoporosis is becoming an important Public Health problem, and is mainly attributed to increase in life expectancy, so increasing diseases linked to age. However, osteoporosis has a multi-factorial etiology ${ }^{(1)}$, and can also be present in spinal cord injuried patients.

Spinal cord injury leads to changes in several organic systems, including Calcium metabolism and bone system ${ }^{(11)}$. Spine cord injury includes loosening of motor function, generally irreversibly, and mechanic stress reduction, due to palsy.

Even though part of osteoporosis physiopathology in spine cord injuried patients can be attributed to simple disuse, it is different from traditional osteoporosis due to neuromuscular system, which, as other body systems, is changed forever. It is believed that alteration due to lack of weight bearing is much more damaging to skeleton than lack of ovarian hormone. Acute withdrawn of mechanic load leads to a monthly reduction of bone mass from 3 to $6 \%$ of the disused bone, while an acute lack of estrogen leads to 4 to $5 \%$ reduction of bone mass over one year. (10).

Osteoporosis clinical picture occurs due to an non proportional increase of bone resorption, for withdrawing the inhibitory control over osteoclasts, an imbalance in bone remodelation (18), and, maybe, due to a local increase of IL-6 below the injury level in paraplegic patients ${ }^{(10)}$.

In this way, the organism is not able to perform remodelation in a similar proportion of resorption, making bones fragile and less capable to face compression and torsion, so increasing fracture incidence. Bone mass reduction is linked to a mandatory loss of bone structure, and consequently, bone strength. For this, bone microarchitecture has an important function in mechanic properties of bones.

Other studies have demonstrated that, in chronic patients of spinal cord injury, the bone mineral content, when compared to normal individuals, is reduced by $25 \%$ at proximal femur and $50 \%$ in proximal tibia ${ }^{(3)}$.

According to JONES et al, 1998, paraplegic patients only have $70 \%$ of Bone Mineral Content (BMC) of control group. These changes can be regional.

Both in paraplegic as tetraplegic patients, bone mass reduction is noticed in all the skeleton but cranial bones, mainly in lower extremities, which were osteopenic. 
Portanto, muitos estudos têm sido realizados na tentativa de melhorar ou prevenir o quadro de osteoporose em lesados medulares. Assim, proporciona um tratamento de reabilitação mais seguro e eficiente para o paciente.

\section{BIOMECÂNICA DO OSSO}

A deposição de osso é parcialmente regulada pela quantidade de tensão imposta ao osso. Ossos com maior tensão e maior curvatura apresentam osteoblastos mais ativos, e assim, ossos mais fortes e mais resistentes. Enquanto ossos não submetidos à tensão, como os ossos de uma pessoa acamada, enfraquecem$\mathrm{se}^{(22)}$. Portanto, a osteoporose por desuso acredita-se ocorrer pela falta de sustentação de peso e de atividade física, provocando uma diminuição no estímulo mecânico necessário para crescimento e remodelamento ósseo.

Carga mecânica promove deformação no osso, e conseqüentemente gera um estímulo para uma resposta óssea local, já postulado por WOLLF em 1870. A força externa aplicada, por unidade de área do osso, pode ser classificada como compressão, tração e cisalhamento, e estas forças aparecem de forma combinada sob carga ${ }^{(42)}$. Estas forças são expressas em unidades de Pascal. Deformação é o resultado da força externa sobre o osso, e é definida pela porcentagem de deformação do osso ou deformação relativa, podendo ser expressa em porcentagem ou em mdeformação.

Atividades diárias geram forças nesses tecidos e essas forças são ampliadas durante a prática de esportes como, atletismo e exercícios pesados $^{(6)}$. O esqueleto humano responde de formas diferentes dependendo da magnitude, distribuição e freqüência de tensão geradas nos ossos, além de possuir diferentes propriedades quando se aplica carga em direções diferentes, sendo classificado como anisotrópico ${ }^{(42)}$. Estímulo mecânico dinâmico é mais eficaz para a formação de osso, pois sob cargas estáticas, as células ósseas se acomodam, tornando-se menos responsivas aos estímulos $^{(41)}$.

O aumento da massa óssea relacionada à atividade física e a diminuição de massa óssea observada em pacientes acamados e em lesados medulares comprovam a grande influência do estímulo biofísico sobre o esqueleto. Portanto, o esqueleto humano é sensível aos estímulos físicos e ambientais e responde a eles através de alterações tanto na massa óssea quanto na arquitetura óssea ${ }^{(14)}$.

Os ossos e tecidos conjuntivos quando deformados geram potenciais elétricos locais, denominados "potenciais gerados por deformação" (SGPS). Esta deformação gera gradientes de pressão dentro dos canalículos e conseqüente deslocamento do fluxo de fluido intersticial existente neles ${ }^{(14)}$. Provavelmente, as células respondem a micro-pressões provenientes de cargas mecânicas. Formas diferentes de compressão sobre células podem gerar respostas diferentes ${ }^{(27)}$. Estudos sugerem que a geração deste
So, many studies have been carried out attempting to improve or prevent osteoporosis occurrence in spine cord injuried patients, thus allowing a safer and more efficient rehabilitation treatment.

\section{BONE BIOMECHANICS}

Bone deposition is partially modulated by stress over the bone. More stressed and curved bones present more active osteoblasts, and so, are stronger and more resistant bones. Meanwhile, bones not submitted to stress, as those of a bedridden people, get weaker (22). So, disuse osteoporosis is believed to be due to lack of weight bearing and physical activity, leading to reduction of mechanical stimuli, needed to bone growth and remodeling.

Mechanic load promotes bone deformation, consequently leading to a local bone response, as postulated by WOLLF in 1870. An external force, when applied to a bone area unit can be classified as compression, traction or shear, and these forces are seen acting in a combined way under load ${ }^{(42)}$. These forces are expressed in Pascal units. Deformation is the result of an external force over the bone, and is defined by the percentage of bone deformation, or relative deformation, and may be expressed as a percentage or in $m$ of deformation.

Daily activities generate forces over these tissues, and these forces are increased during sport practicing, as athleticism and heavy exercise (6). The human skeleton reacts in different ways according to the intensity, distribution and frequency of the stress generated over the bones, besides having different properties when load is applied in different directions, being classified as anisotropic ${ }^{42}$. Dynamic mechanic stimulation is more efficacious for bone formation, since under static loads bone cells become less responsive to stimuli (41).

Bone mass increase related to physical activity, and bone mass reduction observed in bedridden and in spine cord injuried patients confirm the large influence of biophysical stimulus over skeleton. So, human skeleton is sensitive to physical and environmental stimuli, and reacts to them through alteration both in bone mass and bone architecture $^{(14)}$.

Bones and conjunctive tissue when deformed generate local electrical potentials, called "Stress Generated Potentials" (SGPS). This stress generates pressure gradients inside canaliculi, and consequent displacement of interstitial fluid inside them ${ }^{(14)}$. Cells probably react to micro-pressures from mechanic loads. Different forms of pressure over cells can generate different responses ${ }^{(27)}$. Studies suggest that generation of these fluids is important for the bone to notice and respond to mechanical stimuli $(5,14)$. The flow creates a shear force over osteocyte cell membrane. It is believed that osteocytes act as local bone stress sensors. Increase in bone stress leads to an increase in interstitial fluid flow (Fig 1).

Whatever is the origin of SGP, its most important role is the possible relevance in tissue survival (2).

Electromagnetic fields, applied over bones can display a direct 
A

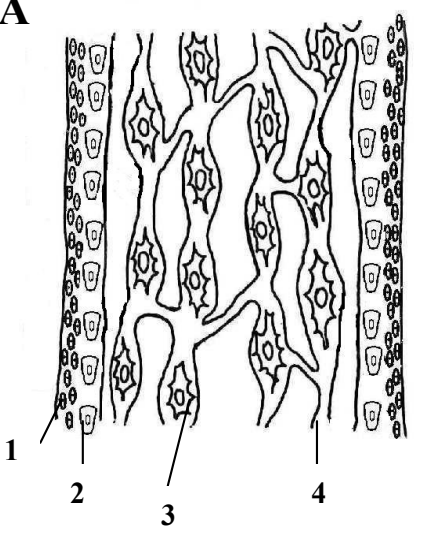

Figura 1 - Representação esquemática de osso.

A) 1- periósteo; 2- osteoblastos; 3- osteócitos; 4- lacunas ósseas.

B) Osso quando submetido à força externa se deforma, e consequentemente promove o deslocamento do fluido intersticial.

C) Fluxo do fluido intersticial promovendo cisalhamento em osteócitos. Estímulo para remodelamento ósseo.

fluido é importante para que o osso perceba e responda aos estímulos mecânicos ${ }^{(5,14)}$. O fluxo cria força de cisalhamento sobre a membrana celular de osteócitos. Acredita-se que osteócitos agem como sensores de tensão ósseo local. O aumento da deformação óssea provoca aumento do fluxo de fluido intersticial (Fig 1).

Qualquer que seja a fonte de SGPs, sua principal importância é o possível papel na sobrevida do tecido(2).

Campos eletromagnéticos aplicados sobre o osso podem exercer efeito direto sobre células ósseas, uma vez que estudos in vivo, mostraram inibição de reabsorção óssea e estímulo de formação óssea ${ }^{(28)}$. Estudos, in vitro, mostraram que osteoblastos sob força de fluido de cisalhamento aumentam os níveis de trifosfato inositol (segundo mensageiro que dispara a liberação de íons cálcio do retículo endoplasmático), AMP cíclico e prostaglandina E.

SGPs e fluxo de fluido podem produzir um número de respostas pelos osteoblastos, incluindo ativação de canais, na membrana celular, aqueles que são operados por voltagem. Outra forma de estímulo é aquele promovido pela ligação da matriz óssea às células. Assim, deformação mecânica na matriz óssea é transmitida para as células ósseas, o que possibilita alterações na regulação da proliferação celular, diferenciação, morfogênese e expressão
Figure 1 - Schematic representation of a bone

A) 1-periosteum; 2- osteoblasts; 3- osteocytes; 4- bone lacunae.

B) When submitted to an external force bone suffers a deformation and consequently promotes interstitial fluid displacement.

C) Interstitial fluid flow promotes shear over osteocytes. Bone remodeling stimulus.

effect over bone cells, once in vivo studies demonstrated bone resorption inhibition and bone formation stimulation ${ }^{(28)}$. In vitro studies demonstrated that osteoblasts, under shear, fluid force increase levels of inositol triphosphate (the second messenger to trigger Calcium ion liberation from endoplasmic reticulum), cyclic AMP and prostaglandin $E$.

SGPS and fluid flow can produce a number of osteoblastic responses, including channel activation at cellular membrane, those which are voltage operated. An other type of stimulus is that driven from bone matrix to cells. Thus, mechanical deformation of bone matrix is transmitted to bone cells, what allows alteration on cellular proliferation regulation, differentiation, morphogenesis and genetic expression. ${ }^{(14)}$

Osteoblastic Calcium channels can be stimulated by stretching allowing an increase of intracellular Calcium, what leads to increase in Calcium resenve liberation to bone matrix. ${ }^{(14)}$.

Given bone deformation is as small as few angstroms, in can be that the best interaction mechanism is through fluid flow generation, ad this allows an increase in nutrients and metabolic transportation inside bone canaliculi.

Deformation appears to reduce bone resorption and to stimulate 
genética $^{(14)}$.

Os canais de cálcio de osteoblastos podem ser estimulados sob estiramento, possibilitando aumento de cálcio intracelular, o que permite aumento na liberação da reserva de cálcio intracelular para a matriz óssea ${ }^{(14)}$.

Sabendo-se que a deformação ocorrida no osso é da ordem de poucos angstroms, talvez o melhor mecanismo de interação seja através da geração de fluxo de fluido, o qual permite aumento de nutrientes e de transporte metabólico dentro dos canalículos dos ossos.

Deformação parece reduzir reabsorção óssea e estimular formação óssea na região submetida à carga ${ }^{(21)}$. PEAD \& LANYON, 1989 observaram número aumentado de osteoblastos formando osso localmente, na região do periósteo, em resposta à carga.

No osso, ocorre o processo de mecanotransdução, ou seja, conversão de estímulo biofísico em um sinal capaz de ser entendido pela célula, a qual obedece uma sequência de acontecimentos ${ }^{(14)}$. Primeiro deve ocorrer a conversão da força mecânica aplicada no osso em um sinal local mecânico que possa ser entendido por um sensor celular.

Nos ossos, as cargas mecânicas geradas por atividades físicas diárias causam deformações no tecido na ordem de 400 a 2000 microdeformações. Durante atividades extenuantes, os ossos podem alcançar tensões de 1500-2000 microdeformações e começa a entrar em falência sob tensões de 7000 microdeformações. A freqüência da carga é proporcional à razão de tensão dentro do tecido ósseo, sendo, aproximadamente, proporcional ao grau de adaptação óssea. Não ocorre aumento da formação óssea com forças externas menores que $0,5 \mathrm{~Hz}$, mas quando a freqüência aumenta para $2 \mathrm{~Hz}$ a formação óssea aumenta em 4 vezes( ${ }^{(43)}$.

Ausência de carga mecânica promove reabsorção óssea aumentada, enquanto uma aplicação de 1000 microdeformações no tecido ósseo na freqüência de 100 ciclos de carga diário inibe reabsorção óssea e mantém massa óssea ${ }^{(37)}$. Tensões mecânicas acima de 1000 microdeformação promove aumento na formação óssea, o que gera aumento da massa óssea ${ }^{(37,44)}$.

Após o sensor celular captar o estímulo deve ocorrer a conversão deste sinal local capturado para um sinal bioquímico que, posteriormente, interferirá no mecanismo celular. Este processo ocorre através das influências causadas pelo fluxo de fluido intersticial explicado acima ${ }^{(14)}$.

A terceira fase inclui a transmissão de sinais bioquímicos, ou seja, o caminho pelo qual o sinal bioquímico captado pelas células sensores é transmitido para células efetoras, as quais aumentam a atividade osteogênica depois de estímulo mecânico. Pode ocorrer pelos osteoblastos de superfície (respondem por $5 \%$ das células de superfície) que captam e respondem ao sinal de maneira a formar osso. No entanto, devido a pequena quantia de osteoblastos ativos na superfície óssea, acredita-se que os osteócitos enviam sinais bioquímicos (prostaglandinas, fatores de crescimento similares à insulina) para células osteoprogenitoras e osteoblastos bone formation at the stressed area ${ }^{(21)}$. PEAD \& LANYON, 1989 observed an increased number of osteoblasts locally producing bone in the region next to periosteum due to load.

A process of mecano-transduction occurs in the bone, that is, a conversion of biophysical stimulus into a signal capable of being understood by cells, which follows a sequence of events ${ }^{(14)}$. First, it must occur a conversion of mechanic force applied to the bone into a local mechanic signal that can be understood by a cellular sensor.

Mechanic charges generated by daily physical activity cause in the bone tissue deformations at a level of 400 to 2000 micro-deformations. During extenuating activities, the bones can reach 1500 to 2000 microdeformations, and starts to break down at a level of 7000 microdeformations. The load frequency is proportional to the reason of stress inside the bone tissue, being approximately proportional to the degree of bone adaptation. Increase of bone formation does not happen at external forces lesser than $0.5 \mathrm{~Hz}$, however, when frequency increases to $2 \mathrm{~Hz}$ bone formation increases four times ${ }^{(43)}$.

Mechanic load absence promotes increased bone resorption, while an application of 1000 micro-deformations over bone tissue at a frequency of 100 daily load cycles inhibits bone resorption and keeps bone mass ${ }^{(37)}$. Mechanic tensions above 1000 microdeformations promote an increased bone formation, what generates bone mass increase ${ }^{(37,44)}$.

After cellular sensor captures the stimulus, this captured sign should be converted into a biochemical sign, which later will interfere on cell mechanism. This process occurs through influences caused by interstitial fluid flow as explained above ${ }^{(14)}$.

Third phase includes transmission of biochemical signs, that is, the way through what the biochemical sign is captured by sensor cells and is transmitted to effector cells, which increase osteogenic activity after mechanic stimulus. It may happen through surface osteoblasts (responsible for $5 \%$ of surface cells) which capture and react to the sign by formatting bone. However, due to the small amount of active osteoblasts at bone surface, it is believed that osteocytes send biochemical signs (prostaglandins, insulin similar growth factors) to osteo-progenitor cells and osteoblasts through canaliculi, which allow cell communication. Osteocytes can not proliferate and produce large amount of bone matrix (14).

Under mechanic stimulus, mechanic-sensitive cells, as osteoblasts, increase their second messenger levels, generally with a fast cyclic AMP increase, which is associated to growth and proliferation. ${ }^{(39,46)}$.

So, 3 to 5 days after a mechanic load is applied, in vivo it is observed collagen aggregation and mineral matrix, a necessary time to intermediate mechanisms between mechanic stimulus and bone formation $(12,20,33)$.

Thus, it is observed that bone response is related to bone tissue deformation and so a proportional adaptation to the applied load will occur. These observation show that electric fields can have anabolic effects over bone tissue. 
através de seus canalículos, os quais permitem comunicação entre as células. Osteócitos não podem proliferar e produz grande quantidade de matriz óssea ${ }^{(14)}$.

Sob estímulo mecânico, as células mecanossensíveis, como osteoblastos, aumentam os níveis de segundo mensageiro, geralmente com elevação rápida de AMPc, o qual está associado com crescimento e proliferação ${ }^{(39,46)}$.

Assim, de 3 a 5 dias após a aplicação de carga mecânica, in vivo, observa-se aumento da aposição de colágeno e matriz mineral, tempo necessário para que ocorrem os mecanismos intermediários entre o estímulo mecânico e a formação óssea ${ }^{(12,20,33)}$.

Portanto, é observado que a resposta óssea está relacionada com a deformação gerada no tecido ósseo, e assim, ocorrerá uma adaptação proporcional à carga aplicada. Estas observações mostram que campos elétricos podem ter efeitos anabólicos sobre o tecido ósseo.

\section{TRAUMA RAQUI MEDULAR}

Imobilização ou desuso é uma condição conhecida que pode ser associada com uma diminuição de massa óssea.

Em pacientes que sofreram alterações neurológicas associadas com paralisias crônicas, como o trauma raqui medular o período de desuso não é revertido.

O mais precoce sinal de perda óssea em pessoas com trauma raqui medular aparece na urina, como relatou Minare, 1974, pesquisando picos de hipercalciuria na $15^{\mathrm{a}}$ semana após a lesão medular em sua população.

Claus-Walker, 1975 acompanhou 32 pacientes quadriplégicos e encontrou elevados níveis de fósforo, cálcio e hidroxyprolina em amostras de urina, dias após a lesão medular, os quais continuaram elevados por 18 meses.

A diminuição de densidade mineral óssea do fêmur pode ser detectada no período de 4 a 16 meses após o trauma raqui medular. Em lesões completas de medula se observa uma maior perda óssea nos primeiros quatro meses, que deve ser consequência das alterações metabólicas sofridas pelos pacientes. Em dezesseis meses a massa óssea se reduz a dois terços da quantidade original(18), sendo que no período entre dezesseis meses a dez anos a perda de massa óssea se estabiliza, e assim, massa óssea é conservada ${ }^{(18,40)}$

Finsen et al 1992, mostraram que o grau de osteoporose aumentou com o passar do tempo, desde o acidente que causou a lesão medular. Diante do fato conhecido de que a diminuição de massa óssea nos indivíduos que sofreram lesão medular é seguida por osteoporose nos ossos abaixo do nível da lesão, Kristjan et al em 1981 concluíram que a ocorrência de fraturas em membros inferiores após a lesão medular é surpreendentemente rara, documentada somente em 23 (4.0\%) de 578 lesados medulares admitidos no Institute of Rehabiliotation Medicine, na New York University, durante 9 anos, e 44 (1.45\%) de 3027 pacientes

\section{RACHI MEDULAR TRAUMA}

Immobilization and disuse is recognized as linked to bone mass reduction

In patients who suffered neurologic changes linked to chronic palsy as rachi medullar trauma, the disuse period is not reverted.

The earliest signal of bone mass loss in rachi medullar trauma patients appears in urine, as reported by Minare, 1974, tracing peaks of hyper-calciuria at $15^{\text {th }}$ week after medullary injury.

Claus-Walker, 1975, followed up 32 patients with quadiplegia, and found high levels of Phosphor, Calcium and Hidroxyproline in urine samples days after medullar injury. These levels were still high for 18 months.

Mineral bone density reduction of femur can be detected in a period from 4 to 16 months after rachi medullar trauma. In complete medullar lesion can be observed a larger bone loss in the first four months, which should be a consequence of metabolic changes suffered by the patients. In 16 months bone mass is reduced by two thirds of the original amount ${ }^{(18)}$, and, in a period between 16 months and 10 years bone mass loss gets stabilized and so, bone mass is preserved $^{(18,40)}$

Finsen et al 1992, reported that the degree of osteoporosis has increased with time, since the causal incident. Considering the known fact that bone mass reduction in medullar injuried patients is followed by osteoporosis below the injury level, Kristjan et al em 1981 concluded that fracture incidence of the lower limbs after medullary injury is surprisingly rare, and found only in 23 (4.0\%) of 578 spine cord injuried patients admitted at the Institute of Rehabilitation Medicine, New York University, in a period of 9 years, and 44 (1.45\%) of 3027 patients registered at National Spinal Cord Injury Data Research Center, Phoenix, Arizona in a 5 years period.

According to the DEPARTMENT OF PHYSICAL MEDICINE AND REHABILITATION, 1997, patients with complete lesions have 10 times more chances of a fracture when compared to incomplete lesion patients, due to the bone mass reduction is closer to the fracture threshold.

Even considering that the number of fractures is not considerable in spine cord injuried patients, this risk does exist.

As osteoporosis development is significant, attempts to revert or to decrease osteoporosis in spine cord injuried patients is a concern of many researchers.

Needham-Shropshire etal, 1997 studied 16 patients with a complete sensitive and motor lesion at a thoracic level. Mean age was 28.8 years, and average post-injury time was 3.8 years. Functional neuromuscular stimulation, using an available commercial system, was performed for 32 times during 12 weeks. It was concluded that the axial load combined with muscular stimuli and exercises did not result in significant changes in mineral bone density in patients with a complete palsy.

MOHR et al, 1997, in a study in spine cord injuried patients used neuromuscular electrical stimulation (NMES) to allow training in a ergometric bicycle and observed that with a 3 times a week training, 
registrados no National Spinal Cord Injury Data Research Center em Phoenix, Arizona por um período de 5 anos.

Segundo o DEPARTMENT OF PHYSICAL MEDICINE AND REHABILITATION, 1997, pacientes com lesões completas têm dez vezes mais chances de sofrer uma fratura quando comparado com lesões incompletas devido à redução de massa óssea sofrida ficar próxima do limiar de fratura.

Mesmo que o número de fraturas não seja considerável em pacientes com lesão medular, este risco existe.

Como o desenvolvimento da osteoporose é bastante significativo, tentativas para reverter ou diminuir a osteoporose em pacientes com lesão medular tem sido uma preocupação de muitos pesquisadores.

Needham-Shropshire et al, 1997 estudaram 16 pacientes com lesão motora e sensorial completa de nível torácico, a idade média dos participantes foi de 28.8 anos e a média de tempo após a lesão foi de 3.8 anos. Foram realizadas 32 estimulações neuromuscular funcional usando um sistema comercial disponível durante 12 semanas. Concluíram que a carga axial combinada com estímulos no músculo e exercícios resistidos não resultaram em mudanças significativas na densidade mineral do osso em pessoas com paraplegia completa.

Em estudo realizado por MOHR, et al, 1997, com pacientes lesados medulares, utilizando-se estimulação elétrica neuromuscular (EENM), para possibilitar o treino em bicicleta ergométrica, foi observado que o treinamento quando realizado três vezes por semana, durante 30 minutos, em um período de 12 meses, aumentou em $10 \%$ a densidade mineral óssea (BMD) da tíbia proximal, sem diferenças na BMD do colo femural e da coluna vertebral. No entanto, quando treinamento passou a ser realizado uma vez por semana, durante seis meses, BMD da tíbia proximal retornou a valores antes do treinamento. O aumento da massa óssea tibial não alterou os marcos bioquímicos de queda óssea, talvez devido ao pequeno aumento conseguido não produzir mudanças sistêmicas mensuráveis. Entretanto, com a EENM ocorre aumento da força muscular em um período relativamente curto ${ }^{(24)}$.

Tentativas para reverter o quadro de osteoporose utilizando-se dietas e drogas não apresentaram muito sucesso. Assim, entre os tratamentos existentes, o ultra-som e a EENM estão sendo estudados para serem utilizados como possíveis tratamentos alternativos.

No Departamento de Ortopedia e Traumatologia do HC-FCMUNICAMP, está sendo desenvolvido estudo relacionado ao uso de estimulação elétrica neuromuscular (EENM) em pacientes que sofreram lesão medular e desenvolveram paraplegia. O controle da osteopenia ou osteoporose, nestes pacientes, é avaliado através da densitometria mineral óssea antes e após os pacientes terem sido submetidos ao ortostatismo e marcha através da EENM. for 30 minutes during 12 months increased bone mineral density (BMD) by $10 \%$ at proximal tibia level, without changes in femoral neck or vertebrae. However, when training started to be done once a week during 6 months, proximal tibia BMD returned back to values before starting the program. Tibial bone mass increase did not change biochemical signs of bone mass reduction, maybe due to the small increase do not measurable systemic changes. However, with NMES an increase in muscle contraction strength occurs in a relatively short period. (24).

Attempts to revert osteoporosis picture using diets and drugs did not succeed. Thus, among existing treatments, ultrasound and NMES are under study aiming to become alternative treatments.

In the Department of Orthopedics and Traumatology of HC-FCMUNICAMP, a study related to Neuromuscular Electrical Stimulation (NMES) is ongoing in spine cord injuried patients with paraplegia. Osteopenia or osteoporosis control in these patients is evaluated through Bone Mineral Densitometry (BMD) before and after patients are submitted to orthostatism and walking with NMES.

\section{BONE MINERAL DENSITOMETRY (BMD)}

Bone mass measure used by researchers was $B M D^{(3,9,31,36,45)}$. This technique is currently considered as gold standard due to its precision, duration, safety and cost effectiveness.

Regions standardized for this examination in general are: lumbar spine, proximal femur, distal radius and all body ${ }^{(34)}$. In a research with patients with spine cord injury, normally bone densitometry is performed in lumbar spine and proximal femur.

In bone mineral densitometry of lower limbs of a normal population, there is no significant difference between left and right side ${ }^{(3)}$, for this reason, right femur is evaluated in spine cord injuried patients. Results are expressed in absolute value or grams per square centimeter of bone mineral density $(B M D)$ in relative value or standard deviation (SD) and percentage.

Values expressed in percentage are correspondent to bone mass loss:

- $(T)$ = related to a young population of the same gender and ethnic group

- $(Z)$ = related to people of equivalent age, sex, weight, ethnic group and height

Current densitometric classification of bone mass loss, agreed in 1994 by World Health Organization is based in T index and involves:

- up to-1SD: normal

- from-1,0 to -2,5SD: osteopenia

- below-2,5SD: osteoporosis

Fracture threshold is BMD below 3.5 SD. 


\section{DENSITOMETRIA MINERAL ÓSSEA (DMO)}

A medida de massa óssea utilizada por pesquisadores foi a densitometria mineral óssea (DMO) $)^{(3,9,31,36,45)}$. Esta técnica atualmente é considerada como padrão em função de sua precisão, duração, segurança e custo.

As regiões padronizadas para o exame, em geral, são: coluna lombar, fêmur proximal, rádio distal e corpo todo ${ }^{(34)}$. Em pesquisa com pacientes portadores de lesão medular, normalmente a densitometria óssea é medida na coluna lombar e região proximal do fêmur.

$\mathrm{Na}$ densitometria mineral óssea dos membros inferiores em uma população normal, não há diferença significativa entre o lado direito e o lado esquerdo(3), por esta razão é aferida a região do fêmur direito nos pacientes com lesão medular. Os resultados são expressos em valores absolutos ou gramas por centímetro quadrado de densidade mineral óssea (DMO) e em valores relativos ou desvios-padrão (DP) e porcentagem.

Os valores expressos em percentuais correspondem à perda de massa óssea:

- $(T)$ = em relação a uma população de jovens de mesmo sexo, peso e grupo étnico

- $(Z)$ = em relação a pessoas da mesma idade, sexo, peso, grupo étnico e altura.

A atual classificação densitométrica de perda de massa óssea aceita, em 1994, pela Organização Mundial da Saúde baseia-se no índice T e compreende:

- até-1DP: normal

- de -1,0 a -2,5DP: osteopenia

- abaixo de -2,5DP: osteoporose

Os limiares para fratura ocorrem com valores de DMO abaixo de 3,5 DP.

As contra-indicações para o exame são:

- gravidez, em função da exposição aos raios X.

- exame recente com radioisótopos.

- presença de implantes ou materiais metálicos no local do exame.

- impossibilidade de posicionamento correto do paciente na mesa de exame.

\section{ULTRA-SOM}

O ultra-som é uma forma de energia mecânica, transmitida para dentro do corpo em ondas de pressão acústica de alta freqüência, capaz de promover a osteogênese. As deformações micromecânicas, ocorridas no tecido ósseo, por ação do ultra-som podem agir como sinalização para a formação de tecido ósseo. As respostas ósseas ocorridas com a utilização do ultra-som são similares àquelas ocorridas sob carga mecânica.

Há evidências de que o ultra-som de baixa intensidade pode acelerar a regeneração óssea(8,13,15,50).
The examination is counter-indicated in:

- pregnancy, due to X Ray exposure

- recent radio-isotope examination

- presence of metallic material and implants at examination site

- impossibility of a correct positioning of the patient in the examination table

\section{ULTRASOUND}

Ultrasound is a form of mechanic energy, transmitted into the body in high frequency acoustic pressure waves, capable to promote osteogesis. Micro-mechanical deformations occurring in bone tissue due to ultrasound activity may act as a sign to bone tissue formation. Bone responses observed with use of ultrasound are similar to the observed under mechanical load.

There are evidences that low intensity ultrasound can accelerate bone regeneration. $(8,13,15,50)$.

Studies demonstrated that low intensity ultrasound presented a direct and persistent effect over blood flow, with an increase in vascularization in animal models fractured regions ${ }^{(19,35)}$. In vitro experiments suggest that low intensity ultrasound can change Calcium ion flow in the first seconds after application (4), besides the possible alteration in growth transformer factor b, type I collagen, specific genes involved in bone repair expression and parathyroidean hormones, observed in in vitro studies $(38,49,51)$.

Low intensity ultrasound can also accelerate bone repair in bone healing interfering diseases. Promising results were found in healing acceleration in diabetic patients (92\%), osteoporotic (95\%), in alcohol and drug addicted (92\%), and those who use drugs that interfere with bone repair ${ }^{(17)}$.

Studies demonstrated that ultrasound treatment increased mineral bone contents, torch peak and rigidity, additionally to accelerate endochondral ossification process ${ }^{(23)}$.

Based on scientific findings, which demonstrate low intensity ultrasound treatment efficacy for acceleration of bone fractures and pseudoarthrosis, besides bone strength increase observed in experimental studies in animal models ${ }^{(47)}$, we are studying low intensity ultrasound effects in amelioration or stabilization of ovarectomized rat osteopenic model.

\section{CONCLUSIONS}

Due to the great incidence of osteoporosis and its consequent implications, it is necessary to have alternative treatments aiming amelioration or stabilization of the problem. So, additional studies, using NMES and low intensity ultrasound keep undergoing in order to identify their effects in osteoporosis. 
Estudos mostraram que o ultra-som de baixa intensidade apresentou efeito direto e persistente sobre o fluxo sangüíneo, com aumento na vascularização em regiões fraturadas em modelo animal(19,35). Experimentos, in vitro, sugerem que o ultra-som de baixa intensidade pode alterar o fluxo de íons cálcio nos primeiros segundos após a aplicação ${ }^{(4)}$, além da possível alteração na síntese de fator $b$ transformador do crescimento, colágeno tipo I, expressão de genes específicos envolvidos no processo de reparo ósseo e hormônios paratiroideanos, observados em estudos in vitro ${ }^{(38,49,51)}$.

O ultra-som de baixa intensidade pode também acelerar o reparo ósseo em pacientes com doenças que interferem na cura óssea. Resultados promissores foram encontrados na aceleração de cura em pacientes diabéticos (92\%), osteoporóticos (95\%), em dependentes de álcool e drogas (92\%), e naqueles que utilizam medicamentos que prejudicam o restabelecimento ósseo ${ }^{(17)}$.

Estudos mostraram que tratamento com ultra-som aumentou conteúdo mineral ósseo, pico de torque e rigidez, além de acelerar o processo de ossificação endocondral(23).

Baseados nos achados científicos, que mostraram a eficácia do tratamento com ultra-som de baixa intensidade para a aceleração do reparo de fraturas ósseas e pseudoartroses, além do aumento da força óssea observado em estudos experimentais em modelos animal(47), estamos estudando os efeitos do ultra-som de baixa intensidade para a melhora ou estabilização do quadro de osteopenia em modelo de rata ovarectomizada.

\section{CONCLUSÕES}

Devido à grande incidência de osteoporose e conseqüêntes implicações decorrentes dela, faz-se necessário tratamentos alternativos que objetivam melhora ou estabilização do quadro clínico. Assim, estudos adicionais, utilizando EENM e ultra-som de baixa intensidade, continuam sendo realizados para observar seus efeitos na osteoporose.

\section{REFERÊNCIAS}

1- AN OFFICIAL PUBLICATION OF THE AMERICAN SOCIETY FOR BONE AND MINERAL RESEARCH. Primer on the metabolic bone diseases and disorders of mineral Metabolism. 4.ed, 1999.

2- BECKER, R.O.: The electrical control of growth processes. Medical Times 95: 657-669, 1967. In: CHARMAN, R.A. Part 4: Strain Generated potencials in Bone na Conective Tissue. Physiotherapy $76^{(11)}$ : 682-689, 1990.

3- BIERING-SFERENSEN, F.; BOHR, $\mathrm{H}_{\text {,; }}$ SCHAADT, MD. : Bone mineral content of the lumbar spine and lower extremities years after spinal cord lesion. Paraplegia 26: 293-301, 1988.

4- BOLANDER, M.E.: Personal communication, 1997.

5- BURGER, E.H.; KLEIN-NULEND, J.: Microgravity and bone cell mechanosensitivity. Bone 22, n. 5, suplemento 1: 127S-130S, 1998.
6- CHARMAN, R.A.: Part 4: Strain Generated potencials in Bone na Conective Tissue. Physiotherapy 76, n. 11: 682-689, 1990.

7- CLAUS-WALKER, J., SPENCER, W.A., CARTER, R.E., HALSTEAD, L.S., MEYER, R.H., CAMPOS, Q.J.: Bone metabolism in quadriplegia: dissociation between calciuria and hydroxyprolinuria. Arch Phys Med Rehabil 56: 327-332, 1975.

8- COLOMBO, S.J.M.: Efeitos da variação da intensidade acústica da consolidação ultra-sônica de fraturas experimentais. Dissertação (Mestrado) - Programa de Pós-Graduação em Bioengenharia, Campus de São Carlos, Universidade de São Paulo, 1992.

9- DEMIREL, G.,YILMAZ, H., PAKER, N., ONEL, S.: Osteoporosis after spinal cord injury. Spinal Cord 36: 822-825,1998.

10- DEMULDER, A.; GUNS, M.; ISMAIL, A.; WILMET, E.; FONDU, P.; BERGMANN, P.: Increased osteoclast-like cells formation in longterm bone marrow cultures from patients with a spinal cord injury. Calcified Tissue International 63: 396-400, 1998.

11- DEPARTMENT OF PHYSICAL MEDICINE AND REHABILITATION: Biomechanical properties of human tibias in long-term spinal cord injury. J Rehabil Res Dev 34 (3): 295-302, jul., 1997.

12- DODDS, R.A.; ALI, N.; PEAD, M.J.; LANYON, L.E.: Early loadingrelated changes in the activity of glucose 6-phosphate dehydrogenase and alkaline phosphatase in osteocytes and periosteal osteoblasts in rat fibulae in vivo. J. Bone Min. Res 8: 261267, 1993.

13- DUARTE, L.R. Estimulação Ultra-Sônica do Calo Ósseo. São Carlos. Tese (Livre-docência) - Escola de Engenharia de São Carlos, Universidade de São Paulo, 1977.

14- DUNCAN, R.L.; TURNER C.H.: Mechanotransduction and the functional response of bone to mechanical strain. Calcified Tissue International 57: 344-358, 1995.

15- DYSON, M. e BROOKES, M.: Stimulation of Bone Repair by Ultrasound. Ultrasound in Medicine and Biology, Suplemento 2: 6166, 1983.

16- FINSEN, V., INTREDAVIC, B., FOUGNER, K.J.: Bone mineral and hormone status in paraplegics. Paraplegia 30: 343-347,1992.

17- FRANKEL, V.H.: Results of prescription use of pulse ultrasound therapy in fracture management. Surgical Techonology International VII (Orthopaedic Surgery): 389-393, 1998.

18- GARLAND, D.E.; STEWART, C.A; ADKINS, R.H.; HU, S.S.; ROSEN, C.; LIOTTA, F.J.; WEINSTEIN, D.A.: Osteoporosis after spinal cord injury. Journal of Orthopaedic Research 10: 371-378, 1992.

19- GOLDBERG, B.B.: Personal communication, 1997.

20- GOODSHIP, A.E.; LANYON, L. E.; MCFIE, H.: Functional adaptation of bone to increased stress. J. Bone Joint Surg. 61A: 539-546, 1979.

21- GROSS, T.S.;EDWARDS, J.L.; MCLEOD, K.J.; RUBIN, C.T.: Strain gradients correlate with sites of periosteal bone formation. Journal of Bone And Mineral Research 12 (6): 982-988, 1997.

22- GUYTON, A.C:. Tratado de Fisiologia Médica. 6 ed. RJ, Guanabara, 1988. 
23- HADJIARGYROU, M.; MCLEOD, K.; RYABY, J.P.; RUBIN, C.: Enhancement of fracture healing by low intensity ultrasound. Clinical Orthopaedics And Related Research 355S: S216-S229, 1998.

24- HARTKOPP, A.; MURPHY, R.J.L.; MOHR, T.; KJAER, M; BIERINGSFERENSEN, F.: Bone fracture during electrical stimulation of the quadriceps in a spinal cord injured subject. Arch Phys Med Rehabil 79: 1133-1136, set, 1998.

25- JONES. L.M.; GOULDIND, A.; GERRARD, D.F.: DEXA: a practical and accurate tool to demonstrate total and regional bone loss, lean tissue loss and fat mass gain in paraplegia. Spinal Cord 36: 637640, 1998.

26- KRISTJAN, T., RAGNARSSON, M.D., SELL, G.H.: Lower Extremity Fractures After Spinal Cord Injury: A Retrospective Study. Arch Phys Med Rehabil 62: 418-423, 1981.

27- MAC DONALD, A.G.; FRASER, P.J.: The transduction of very small hydrostatic pressures. Comparative Biochemistry and Physiology Part A: Molecular \& Integrative Physiology 122 (1): 13-36, 1999.

28- MC LEOD, K.J.; RUBIN, C.T.: The effect of low-frequency electrical fields on osteogenesis. J. Bone Jt Surg 74A: 920-929, 1992.

29- MINARE, P. et al.: Quantitative histological data on disuse osteoporosis: comparision with biological data. Calcif Tissue Res 17: 57-73, 1974.

30- MOHR, T; PÆEDENPHANT, J.;BIERING-SFERENSEN, F.; GALBO, H.; THAMSBORG, G.; KJAER, M.: Increased bone mineral density after prolonged electrically induced cycle training of paralyzed limbs in spinal cord injured man. Calcif Tissue Int 61: 22-25, 1997.

31- NEEDHAM- SHROPSHIRE, B.M., BROTON, J.G., KLOSE, K.J., LEBWOHL, N., GUESS, R.S., JACOBS, P.L.: Evolution of a Training Program for Persons With SCI Paraplegia Using the Parastep 1 Ambulation System: Part 3 Lack of Effect on Bone Mineral Density: Arch Phys Med Rehabil 78: 799-803,1977.

32- PEAD, M.J.; LANYON, L.E.: Indomethacin modulation of loadrelated stimulation of new bone formation in vivo. Calcified Tissue International 45: 34-40, 1989.

33- PEAD, M.J.; SUSWILLO, R.; SKERRY, T.M.; VEDI, S.; LANYON, L.E.: Increased ${ }^{3} \mathrm{H}$ uridine levels in osteocytes following a single short period of dynamic bone loading in vivo. Calcified Tissue International 43: 92-96, 1988.

34- PLAPLER, P.G., MEIRELLES, E.S.: Osteoporose e Exercícios; Greve, J.M.A., Amatuzzi, M.M.; Medicina de Reabilitação Aplicada à Ortopedia e Traumatologia, São Paulo, ed. Roca Ltda, 1999, p. 361-380.

35- RAWOOL , D.; GOLDBERG, B.; FORSBERG, F, et al: Power doppler assessment of vascular changes during fracture treatment with low intensity ultrasound. Trans 83rd Radiol. Soc. North. Am. 83: 421, 1997.

36- ROBERTS, D., LEE, W., CUNEO, R. C. , WITTMANN, J., WARD, G., FLATMAN, R., MCWHINNEY, B., HICKMAN, P. E.: Longitudinal Study of Bone Turnover after Acute Spinal Cord Injury. Journal of Clinical Endocrinology and Metabolism 83: 415-422, 1998.

37- RUBIN, C.T.; LANYON, L.E.: Regulation of bone mass by mechanical strain magnitude. Calcified Tissue International 37: 411-417, 1985.
38- RYABY, J.T.; MATHEW, J.; DUARTE-ALVES, P.: Low intensity pulsed ultrasound affects adenylate cyclase and TGF-b synthesis in osteoblastic cells. Transactions Orthopaedic Research Society 17: 590, 1992

39- SANDY, J.R.; FARNDALE, R.W.: Second messengers: regulators of mechanically induced tissue remodelling. Eur. J. Orthod 13: 271278, 1991

40- SINAKI, M.: Musculoskeletal Rehabilitation. In: RIGGS, B. L; MELTON, L.J.III Osteoporosis: etiology, diagnosis, and management. 2. ed. New York, Lippincott-Raven. Cap.20, p. 435-473, 1995.

41- TURNER, C. H.: Three rules for bone adaptation to mechanical stimuli. Bone 23 (5): 399-407, 1998.

42- TURNER, C.H.; BURR, D.B. Basic biomechanical measurements of bone: a tutorial. Bone 14,: 595-608, 1993.

43- TURNER, C.H.; FORWOOD, M.R.; OTTER, M.W.: Mechanotransduction in bone: Do bone cells act as sensors of fluid flow? FASEB J. 8: 875-878, 1994.

44- TURNER, C.H.; FORWOOD, M.R.; RHO, J.; YOSHIKAWA, T.: Mechanical loading thresholds for lamellar and woven bone formation. J. Bone Min. Res. 9: 87-97, 1994.

45- UEBELHART, D., DEMIAUX-DOMENECH, B., ROTH, M., CHANTRINE, A.: Bone metabolism in spinal cord injured individuals and in others who have prolonged immobilisation. A review. Paraplegia 33: 669-673,1995.

46- VANDERBURGH, H.H.: Mechanical forces and their second messengers in stimulating cell growth in vitro. Am J. Physiol 262: R350-R355, 1992.

47- WANG, S-J; LEWALLEN, D.G.; BOLANDER, M.E.; CHAO, E.Y.S.; ILSTRUP, D.M.; GREENLEAF, J.F.: Low intensity ultrasound treatment increases strength in a rat femoral fracture model. Journal of Orthopaedic Research 12 (1): 40-47, 1994.

48- WOLLF, J.: The law of bone remodeling, traduzido por Maquet, p.; Furlong, R. New York, Springer, 1986.

49- WU, C.C.; LEWALLEN, D.G.; BOLANDER, M.E.; BRONK, M.E.; KINNICK, R.; GREENLEAF, J.F.: Exposures to low intensity ultrasound stimulates aggrecan gene expression by cultured chondrocytes. Transactions Orthopaedic Research Society 21: 622, 1996.

50- XAVIER, C.A.M. e DUARTE, L.R.: Aplicação clínica. Revista Brasileira de Ortopedia 18 (3): 73-80, 1983.

51- YANG, K-H; PARVIZI, J.; WANG, S-J; LEWALLEN, D.G.; KINNICK, R.R.; GREENLEAF, J.F.; BOLANDER, M.E.: Exposure to low-intensity ultrasound increases aggrecan gene expression in a rat femur fracture model. The Journal of Orthopaedic Research 14 (5): 802-809, 1996. 